\title{
Response of heterotrophic and autotrophic microbial plankton to inorganic and organic inputs along a latitudinal transect in the Atlantic Ocean
}

\author{
S. Martínez-García ${ }^{1}$, E. Fernández ${ }^{1}$, A. Calvo-Díaz ${ }^{2, *}$, E. Marañón ${ }^{1}$, X. A. G. Morán ${ }^{2}$, and E. Teira ${ }^{1}$ \\ ${ }^{1}$ Departamento Ecoloxía e Bioloxía Animal, Universidade de Vigo, Campus Lagoas-Marcosende 36310 Vigo, Spain \\ ${ }^{2}$ Instituto Español de Oceanografía, Centro Oceanográfico de Xixón, Camín de L’Arbeyal s/n, 33212 Xixón, Spain \\ *Present address: Department of Biological Oceanography, Royal Netherlands Institute for Sea Research (NIOZ), P.O. Box \\ 59, 1790 AB Den Burg, The Netherlands; and Department of Marine Biology, University of Vienna, Althanstrasse 14, 1090 \\ Vienna, Austria
}

Received: 22 December 2009 - Published in Biogeosciences Discuss.: 19 January 2010

Revised: 22 April 2010 - Accepted: 10 May 2010 - Published: 25 May 2010

\begin{abstract}
The effects of inorganic and/or organic nutrient inputs on phytoplankton and heterotrophic bacteria have never been concurrently assessed in open ocean oligotrophic communities over a wide spatial gradient. We studied the effects of potentially limiting inorganic (nitrate, ammonium, phosphate, silica) and organic nutrient (glucose, aminoacids) inputs added separately as well as jointly, on microbial plankton biomass, community structure and metabolism in five microcosm experiments conducted along a latitudinal transect in the Atlantic Ocean (from $26^{\circ} \mathrm{N}$ to $29^{\circ} \mathrm{S}$ ).

Primary production rates increased up to 1.8 -fold. Bacterial respiration and microbial community respiration increased up to 14.3 and 12.7-fold respectively. Bacterial production and bacterial growth efficiency increased up to 58.8-fold and 2.5-fold respectively. The largest increases were measured after mixed inorganic-organic nutrients additions. Changes in microbial plankton biomass were small as compared with those in metabolic rates. A north to south increase in the response of heterotrophic bacteria was observed, which could be related to a latitudinal gradient in phosphorus availability. Our results suggest that organic matter inputs will result in a predominantly heterotrophic versus autotrophic response and in increases in bacterial growth efficiency, particularly in the southern hemisphere. Subtle differences in the initial environmental and biological conditions are likely to result in differential microbial responses to inorganic and organic matter inputs.
\end{abstract}

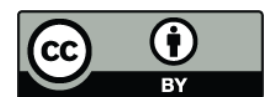

Correspondence to: S. Martínez-García (sandra@uvigo.es)

\section{Introduction}

The nature of nutrient limitation of phytoplankton and bacterial production in open ocean waters is known to vary over spatial and temporal scales (Cullen et al., 1992; Arrigo 2005; Church 2008; Saito et al., 2008). Nitrogen is the proximal limiting nutrient of phytoplankton growth in the oligotrophic tropical and subtropical Atlantic over physiological and/or ecological time scales (Graziano et al., 1996; Mills et al., 2004, 2008; Moore et al., 2008), whereas P and Fe, as limiting nutrients for $\mathrm{N}_{2}$ fixation (Falkowski 1997; Tyrrell 1999), are responsible for $\mathrm{N}$-limitation of primary production at geological time scales. It has also been suggested that increasing atmospheric inputs together with enhanced nitrogen fixation rates may lead to phosphorus limitation in the tropical North Atlantic Ocean (Wu et al., 2000, Ammerman et al, 2003; Mather et al., 2008).

Some nutrient enrichment bioassays have demonstrated that $\mathrm{N}$ and $\mathrm{P}$ are co-limiting heterotrophic bacterial metabolism in oligotrophic environments (Thingstad and Rassoulzadegan 1995; Rivkin and Anderson 1997; Joint et al., 2002; Mills et al., 2008); whereas many others report organic carbon as the limiting or co-limiting factor (Church et al., 2000; Carlson et al., 2002; Alonso-Sáez et al., 2007; Van Wambeke et al., 2008; among others).

Atmospheric inputs have been recognized as an important source of nutrients for upper ocean microbial communities (Baker et al., 2007). Recent studies suggest that atmospheric water-soluble organic nitrogen entering central ocean regions accounts for up to $30 \%$ of the total atmospheric nitrogen inputs into these marine areas (Cornell et al., 1995; Duce et

Published by Copernicus Publications on behalf of the European Geosciences Union. 
al., 2008 and references therein). Increases in nutrient inputs associated to atmospheric deposition have been shown to change the structure and metabolism of coastal microbial planktonic communities (Paerl 1997; Peierls and Paerl, 1997; Seitzinger and Sanders, 1999) and similar effects may be expected over open ocean microbial communities. However, the effects of inorganic and/or organic nitrogen inputs on both phytoplankton and heterotrophic bacteria remain poorly studied. To the best of our knowledge, only the study by Davidson et al. (2007) have concurrently addressed the differential effect of inorganic versus organic nitrogen inputs on both phytoplankton and bacteria in coastal waters

The aim of our study was to assess the response of microbial planktonic communities to inorganic and/or organic nutrient loading over a large spatial scale, in order to determine general patterns in the linkage between the type of input, the initial biotic and abiotic conditions, and the interactions between microbial compartments

Specifically, we tested the differential effect of inorganic $(\mathrm{N}, \mathrm{P}$ and $\mathrm{Si}$ ) versus organic $(\mathrm{N}$ and $\mathrm{C})$ nutrients inputs added separately as well as jointly on autotrophic and heterotrophic microbial communities along a latitudinal gradient in the upper oligotrophic Atlantic Ocean.

\section{Materials and methods}

Five enrichment microcosm experiments were performed during cruise Trynitrop I on board "BIO-Hespérides" from 16th November to 16th December 2007 (Fig. 1 and Table 1). Water for the experiments was collected along a latitudinal transect in the Atlantic Ocean (approximately from $26^{\circ} \mathrm{N}$ to $29^{\circ} \mathrm{S}$ latitude) (Fig. 1). At each sampling station, vertical profiles of temperature, salinity and in situ fluorescence were obtained using a Conductivity-Temperature-Depth sensor (CTD) attached to a rosette down to $300 \mathrm{~m}$.

Water samples were collected before dawn from 10-15 m into 15-L acid-clean Niskin bottles and filtered through $150 \mu \mathrm{m}$ pore size net to remove larger zooplankton. Subsequently, eight 12-L acid-washed polycarbonate bottles were gently filled under dim light conditions.

\subsection{Experimental design}

Following sample collection, nutrients were added to the experimental bottles. The experimental design included duplicates for a series of four treatment levels: 1. Control: no additions made; 2. Inorganic Addition Treatment: $0.5 \mu \mathrm{mol} \mathrm{l}^{-1}$ nitrate $\left(\mathrm{NO}_{3}^{-}\right), 0.5 \mu \mathrm{mol} \mathrm{l}^{-1}$ ammonium $\left(\mathrm{NH}_{4}^{+}\right)$, $0.05 \mu \mathrm{moll}^{-1}$ phosphate $\left(\mathrm{PO}_{4}^{3-}\right)$ and $0.1 \mu \mathrm{moll}^{-1}$ silicate $\left(\mathrm{SiO}_{4}^{2-}\right)$; 3. Organic Addition Treatment: $0.5 \mu \mathrm{mol} 1^{-1}$ glucose and $0.5 \mu \mathrm{moll}^{-1}$ of an equimolar mixture of 18 aminoacids; 4. Mixed Addition Treatment: combination of inorganic and organic additions. The ratio N:Si:P of the additions performed was 20-30:2:1 depending on the addi-

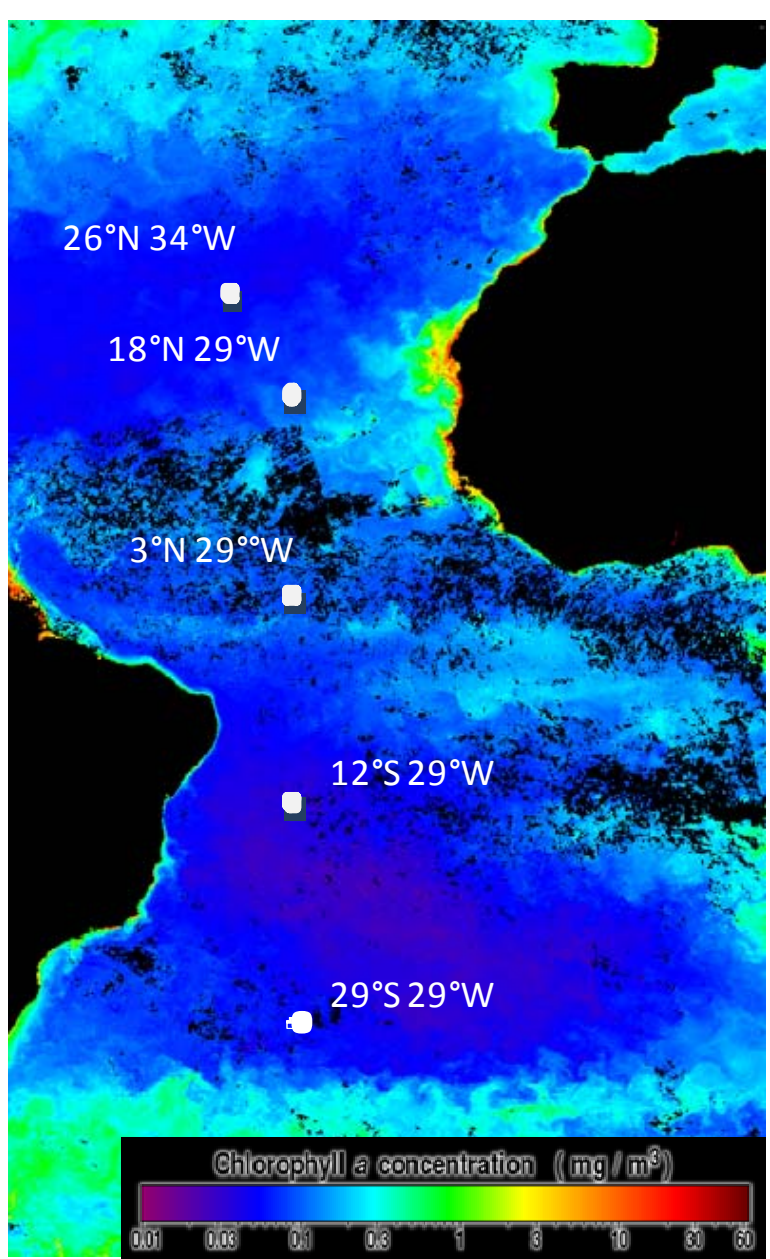

Fig. 1. Map of sampling stations superimposed on a SeaWifs chlorophyll- $a$ monthly composite image (November 2007).

Table 1. Summary of initial conditions for each experiment. Sampling depth was $10 \mathrm{~m}$ excepting for experiment at $12^{\circ} \mathrm{S} 29^{\circ} \mathrm{W}$ $(15 \mathrm{~m})$. Nutricline depth was estimated as the first depth where nitrate concentration is $>0.5 \mu \mathrm{M}$. DCM, deep chlorophyll maximum. N/A, not available.

\begin{tabular}{lccccc}
\hline Experiment & $26^{\circ} \mathrm{N}$ & $18^{\circ} \mathrm{N}$ & $3^{\circ} \mathrm{N}$ & $12^{\circ} \mathrm{S}$ & $29^{\circ} \mathrm{S}$ \\
& $34^{\circ} \mathrm{W}$ & $29^{\circ} \mathrm{W}$ & $29^{\circ} \mathrm{W}$ & $29^{\circ} \mathrm{W}$ & $29^{\circ} \mathrm{W}$ \\
\hline Surface Temp. $\left({ }^{\circ} \mathrm{C}\right)$ & 24.6 & 25.8 & 27.9 & 25.6 & 22.0 \\
Surface Salinity & 37.57 & 36.73 & 35.28 & 36.94 & 35.85 \\
DCM depth (m) & 120 & 100 & 75 & 140 & 100 \\
Nutricline depth (m) & 150 & 80 & 50 & 140 & 100 \\
$\mathrm{Surface}$ Nutrients & & & & & \\
$\mathrm{NO}_{3}^{-}\left(\mathrm{nmol} \mathrm{L}^{-1}\right)$ & N/A & 116 & 117 & 124 & 113 \\
$\mathrm{NH}_{4}^{+}\left(\mathrm{nmol} \mathrm{L}^{-1}\right)$ & N/A & 17 & 12 & 17 & N/A \\
$\mathrm{PO}_{4}^{-3}\left(\mathrm{nmol} \mathrm{L}^{-1}\right)$ & N/A & 40 & N/A & 70 & 80 \\
\hline
\end{tabular}


tion made (inorganic or mixed addition treatment). No trace metal-clean techniques were available to collect the required sample volume, thus we decided not to include Fe in the experimental design. Organic additions consisted in additions of glucose and aminoacids as they are the more abundant organic labile substances identified in seawater. Organic nitrogen additions were performed to simulate previously reported increases in atmospheric bioavailable water-soluble organic nitrogen inputs (Seitzinger and Sanders, 1999; Mace et al., 2003; Duce et al., 2008). Glucose was also included as atmospheric depositions can contain non-nitrogenous organic constituents (Jurado et al., 2008; Pulido-Villena et al., 2008; Reche et al., 2009). Pulido-Villena et al. (2008) reported an increase of dissolved organic carbon (DOC) of ca. $3 \mu \mathrm{mol} \mathrm{Cl} 1^{-1}$ after a dust deposition event in the surface mixed layer of the Western Mediterranean. Therefore, our addition of ca $5 \mu \mathrm{mol} \mathrm{Cl}^{-1}$ in the form of amino acids and glucose, compare reasonably well, in terms of DOC concentration, with the observed DOC increases associated with a natural event of dust deposition.

Experimental bottles were maintained in an in-door incubation chamber which simulated in situ temperature and mean irradiance intensity (cool white light from fluorescent tubes, photoperiod $=12-14 \mathrm{~h}$, and constant light intensity $=240 \mu \mathrm{E} \mathrm{m}^{-2} \mathrm{~s}^{-1}$ ). Using the measured values of incident irradiance and vertical extinction coefficient, we determined that the irradiance used during the experiments was similar (within 20\%) to the mean irradiance reaching the sampling depth over the light period (from dawn to dusk). Experiments lasted 3 days and samples were taken every $24 \mathrm{~h}$ to monitor changes in microbial community structure and function.

\subsection{Chemical and biological analysis}

\subsubsection{Nutrients}

The concentration of nitrate and ammonium was determined on-board on fresh samples with a Technicon segmented-flow auto-analyser and using modified colorimetric protocols that allow to lower the detection limit to $2 \mathrm{nmol}^{-1}$ (Kerouel and Aminot, 1997; Raimbault et al., 1990). Phosphate concentration was determined using standard procedures (Tréguer and Le Corre, 1975).

\subsubsection{Size-fractionated chorophyll $a$}

Size-fractionated chlorophyll $a$ (chl $a$ ) concentrations were measured in $250 \mathrm{ml}$ water samples which were filtered sequentially through 2 and $0.2 \mu \mathrm{m}$ polycarbonate filters. After extraction with $90 \%$ acetone at $4^{\circ} \mathrm{C}$ overnight at dark, chlorophyll $a$ fluorescence was determined with a TD-700 Turner Designs fluorometer calibrated with pure chl $a$.

\subsubsection{Primary Production (PP)}

Four $75 \mathrm{ml}$ acid-cleaned polystyrene bottles (3 light and 1 dark) were filled and inoculated with $277-740 \mathrm{kBq}(7.5-$ $20 \mu \mathrm{Ci}) \mathrm{NaH}^{14} \mathrm{CO}_{3}$. Samples were incubated for $12-14 \mathrm{~h}$ in the same incubation chamber as the experimental bottles. After the incubation period, samples were sequentially filtered through 2 and $0.2 \mu \mathrm{m}$ polycarbonate filters at very low vacuum $(<50 \mathrm{~mm} \mathrm{Hg})$. Filters were processed to assess ${ }^{14} \mathrm{C}$ incorporation as described in Marañón et al. (2001).

\subsubsection{Bacterial Heterotrophic Production (BP)}

The $\left[{ }^{3} \mathrm{H}\right]$ leucine incorporation method (Kirchman et al., 1985), modified as described by Smith and Azam (1992), was used to determine Leu incorporation rates (LIR). Samples were incubated for 1.5 to $2 \mathrm{~h}$ in the same incubation chamber as the experimental bottles. Dilution experiments in order to determine the in situ leucine to carbon conversion factors $(\mathrm{CF})$ were performed with enriched water following the methods detailed elsewhere (Calvo-Díaz and Morán, 2009). The CFs obtained at the station where the enrichment microcosm experiments were performed (or an average between the $\mathrm{CF}$ values from the nearest available stations) were used to calculate bacterial biomass production rates from Leu uptake rates (CF range: $0.17-0.21 \mathrm{~kg} \mathrm{C} \mathrm{mol} \mathrm{Leu}^{-1}$ ). Bacterial growth efficiency (BGE) was calculated as: Bacterial production/(Bacterial production+ Bacterial respiration).

\subsubsection{In vivo Electron Transport System (ETS)}

ETS activity rate was used as estimator of community respiration (CR). Size-fractionated in vivo ETS activity rates were measured using the in vivo INT method (Martínez-García et al., 2009). Four $250 \mathrm{ml}$ dark bottles were filled from each microcosm bottle. One bottle was immediately fixed by adding formaldehyde ( $2 \% \mathrm{w} / \mathrm{v}$ final concentration) and used as killed-control. Samples were incubated at the same temperature that the microcosm bottles and in dark conditions. After incubation (4-6h), samples were filtered sequentially through 0.8 and $0.2-\mu \mathrm{m}$ pore size polycarbonate filters. Bacterial respiration (BR) was operationally defined as ETS activity of the $<0.8 \mu \mathrm{m}$ size-fraction following the extensive review by Robinson (2008). In order to transform ETS activity in carbon respiration a R/ETS ratio of 12.8 (MartínezGarcía, et al., 2009) and a respiratory quotient (RQ) of 0.8 (Williams and del Giorgio, 2005) were used.

\subsubsection{Flow cytometry}

The abundance of Synechococcus, Prochlorococcus, picoeukaryotes and heterotrophic bacteria was determined on board on $0.6 \mathrm{ml}$ fresh and $0.4 \mathrm{ml}$ frozen samples (autotrophic and heterotrophic groups, respectively) using a Becton Dickinson FACSCalibur flow cytometer equipped with a laser emitting at $488 \mathrm{~nm}$ (Gasol and del Giorgio, 
2000). Samples for heterotrophic bacteria were preserved with $1 \%$ paraformaldehyde $+0.05 \%$ glutaraldehyde and frozen at $-80^{\circ} \mathrm{C}$ until analysis on board. Prior to analysis, heterotrophic bacteria were stained with $2.5 \mathrm{mM}$ SybrGreen DNA fluorochrome. Picoplankton groups were identified on the basis of their fluorescence and light side scatter (SSC) signatures. Synechococcus and Prochlorococcus cyanobacteria and eukaryotic cells were identified in plots of SSC versus red fluorescence (FL3, >650 nm), and orange fluorescence (FL2, $585 \mathrm{~nm}$ ) versus FL3, whereas three groups of heterotrophic bacteria were distinguished by their green fluorescence (FL1, $530 \mathrm{~nm}$ ) after SybrGreen staining: very high (vHNA), high (HNA) and low (LNA) nucleic acid content bacteria.

Two empirical calibrations specific for this dataset between SSC or forward scatter (FSC) and cell diameter, as explained in Calvo-Díaz and Morán (2006), were used to estimate biovolume (BV) for picophytoplanktonic cells (diameter cell $=2.14 \times \mathrm{SSC}+0.54 ; n=30, r^{2}=0.87$ ) and for heterotrophic bacterioplankton $(\mathrm{BV}=0.058 \times \mathrm{FSC}+0.013$; $n=13, r^{2}=0.60$ ). BV was finally converted into biomass by using the following volume-to-carbon conversion factors for autotrophic groups: $230 \mathrm{fg} \mathrm{C}^{-3} \mathrm{~m}^{-3}$ for Synechococcus, $240 \mathrm{fg} \mathrm{C} \mu \mathrm{m}^{-3}$ for Prochlorococcus and $237 \mathrm{fg} \mathrm{C} \mathrm{m}^{-3}$ for picoeukaryotes (Worden et al., 2004). Heterotrophic bacterial biomass (BB) was calculated by using the allometric relationship of Gundersen et al. (2002): bacterial biomass $\left(\right.$ fg C cell $\left.{ }^{-1}\right)=108.8 \times \mathrm{BV}^{0.898}$.

\subsection{Statistical analysis}

The Pearson coefficient was used to analyse correlations between nutricline depth and biomasses and rates at the sampling stations, as the complete set of variables followed normal distributions. Given the low sample size $(n=5)$, a power analysis was conducted using the GPower 3.1.0 software (Faul et al., 2007). We computed the adequate significance level for each slope which balances the likelihood of type I and type II errors. The power of the statistical analysis remained always $>0.8$ and correlations were considered significant when the p-value was bellow the significance level obtained using GPower 3.1.0.

A repeated measure ANOVA (RMANOVA) was conducted to assess time (within subject factor), treatment (between subject factor, nutrient additions), and experiment (between subject factor, sampling location) effects. All data fitted a normal distribution (Kolmogorov-Smirnov test); however, even after $\log$ or arcsine data transformation, the homogeneity of covariance matrices failed for some datasets. For the latter case we applied the Huynh-Feldt adjustment to correct P-values (Scheiner and Gurevitch, 1993). A Bonferroni post-hoc test was conducted to assess the effect of each addition treatment.

In order to compare the effect of different nutrient additions on the biomasses and rates, we calculated response ra-
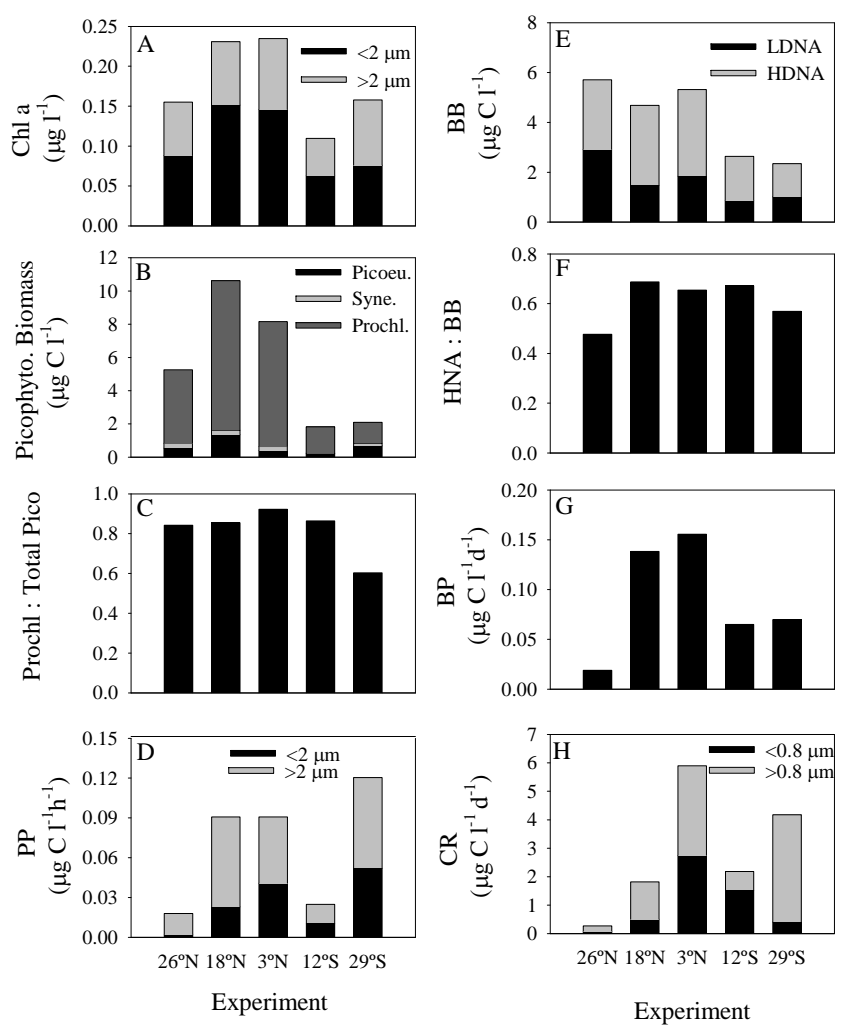

Fig. 2. Initial biological conditions at the sampling stations. (A), Chl $a$, size-fractionated chlorophyll $a\left(\mu \mathrm{gl}^{-1}\right)$; (B), Picophyto.Biomass, picophytoplankton biomass $\left(\mu \mathrm{g} \mathrm{Cl}^{-1}\right)$; (C), Proch:Total Pico, Prochlorococcus: Total picophytoplankton biomass ratio; (D), PP, size-fractionated primary production $\left(\mu \mathrm{g} \mathrm{Cl}^{-1} \mathrm{~h}^{-1}\right) ;(\mathbf{E}), \mathrm{BB}$, heterotrophic bacterial biomass $\left(\mu \mathrm{g}^{-1}\right)$; (F), vHNA: BB, vHNA : Bacterial biomass; (G), $\mathrm{BP}$, bacterial production $\left(\mu \mathrm{g} \mathrm{Cl}^{-1} \mathrm{~d}^{-1}\right) ;(\mathrm{H}), \mathrm{CR}$, size-fractionated community respiration estimated from in vivo ETS activity $\left(\mu \mathrm{g} \mathrm{C} 1^{-1} \mathrm{~d}^{-1}\right)$.

tios ( $\mathrm{RR}$ ) as $\mathrm{AT} / \mathrm{C}$, where $\mathrm{AT}$ and $\mathrm{C}$ are the time integrated value of the variable in the Addition Treatment and the Control, respectively. In the case of biomasses time-averaged values were used. Values presented in this work were integrated (or averaged in the case of biomasses) from 0 to $72 \mathrm{~h}$ incubation since no relevant differences were found between ratios calculated from 0 to 24,48 , or $72 \mathrm{~h}$.

\section{Results}

\subsection{Initial conditions}

Initial conditions for each experiment are presented in Table 1 and Fig. 2. The depth of the nutricline, which is a proxy for nutrient supply into the euphotic layer, was significantly (GPower 3.1.0. correction was applied when necessary as explained in Material and Methods section) and negatively correlated with chlorophyll $a$ concentration $(r=-0.87, p=$ $0.06 ; n=5)$, primary production $(r=-0.77, p=0.13 ; n=$ 
5), bacterial production $(r=-0.94, p=0.02 ; n=5)$ and community respiration $(r=-0.78, p=0.12 ; n=5)$. These negative relationships illustrate the role of vertical nutrient fluxes in controlling the biomass and metabolism of microbial plankton (Marañón, et al., 2003).

Phytoplankton biomass estimated as chlorophyll $a(\mathrm{chl} a)$ concentration, and primary production rates were lower at those stations located in the center of the gyres $\left(26^{\circ} \mathrm{N}\right.$ and $12^{\circ} \mathrm{S}$ ), where the deepest nutriclines were found (Fig. 2a). The biomass of heterotrophic bacteria was higher at stations located in the northern hemisphere than in the southern hemisphere (Fig. 2e).

The highest bacterial production rates were registered at $18^{\circ} \mathrm{N}$ and $3^{\circ} \mathrm{N}$ coinciding with the shallowest nutriclines, and an extremely low value was measured at $26^{\circ} \mathrm{N}$ where the deepest nutricline was found (Fig. $2 \mathrm{~g}$ ). The lowest community respiration rates, estimated as in vivo ETS activity, were also registered at $26^{\circ} \mathrm{N}$ and largest values at $3^{\circ} \mathrm{N}$ and $29^{\circ} \mathrm{S}$ In all cases, differences in metabolic rates among sampling sites were more pronounced than those in biomass (Fig. 2).

\subsection{Autotrophic responses to nutrient additions}

The responses of phytoplankton differed among experiments (Fig. 3a-f). Autotrophic biomass, estimated as chl $a$ concentration, decreased with incubation time in the experiments performed in the northern hemisphere (Fig. 3a). At $18^{\circ} \mathrm{N} \mathrm{a}$ slight increase in chl $a$ (mostly due to the $>2 \mu \mathrm{m}$ fraction) was observed in the mixed treatment. In the experiments conducted in the southern hemisphere, $\operatorname{chl} a$ increased after inorganic additions (inorganic and mixed treatments) at $12^{\circ} \mathrm{S}$ and after mixed additions at $29^{\circ} \mathrm{S}$ (Fig. 3a). In the experiments conducted in the northern hemisphere, the relative contribution of Prochlorococcus to total picophytoplankton biomass (Prochl/Total Pico) showed a marked decrease with incubation time both in the control and the addition treatments (Fig. 3c).

Total primary production decreased in the first $24 \mathrm{~h}$ at $26^{\circ} \mathrm{N}$ and $3^{\circ} \mathrm{N}$ (Fig. 3d). Enhancements of primary production rates relative to the controls, mostly due to the $>2 \mu \mathrm{m}$ phytoplankton, were found in the nutrient addition treatments in all experiments except at $3^{\circ} \mathrm{N}$ (Fig. $3 \mathrm{~d}$ and e). The highest increases were registered in the mixed treatment bottles.

Primary production to chlorophyll ratios ( $\mathrm{PP} / \mathrm{chl} a$ ) also showed different patterns among experiments (Fig. 3f).

Incubation time and experiment had a significant effect on all variables ( $p<0.001$, RMANOVA). The effect of the addition treatments on phytoplankton biomass, on the percentage of $<2 \mu \mathrm{m}$ chl $a$, on the relative abundance of Prochlorococcus, on primary production and on $\mathrm{PP} / \mathrm{chl} a$ ratio was not significant ( $p>0.05$, RMANOVA), but significant effects of nutrient additions on the percentage of $<2 \mu \mathrm{m}$ primary production were found ( $p<0.05$, RMANOVA). A significant decrease of the $\% \mathrm{PP}<2 \mu \mathrm{m}$ was related to inorganic additions ( $p<0.05$, Bonferroni post-hoc test, Table 2$)$.

The response ratios illustrate the direction and magnitude of autotrophic responses observed in the experiments (Fig. 4a-f). A response ratio larger than one entails higher values in the addition treatment than in the control, e.g. a positive response to the addition. No large changes in the addition treatments relative to the control were found for phytoplankton biomass and size distribution. Prochlorococus tended to decrease in abundance, relative to the other picophytoplankton groups, when nutrients were added, except at $26^{\circ} \mathrm{N}$ (Fig. 4c). The increase of primary production after the additions was slightly higher than that of chl $a$. Primary production enhancements were maximum (up to 1.8 -fold relative to control) in the mixed treatment bottles at $18^{\circ} \mathrm{N}$ and $29^{\circ} \mathrm{S}$. The relative contribution of $<2 \mu \mathrm{m}$ fraction to total primary production decreased after the additions except at $26^{\circ} \mathrm{N}$, in which organic nutrients additions resulted in an increase of the relative contribution of $<2 \mu \mathrm{m}$ fraction to total primary production (Fig. 4e).

\subsection{Heterotrophic microbial responses to nutrient additions}

Heterotrophic bacteria were greatly stimulated after organic nutrient additions (Fig. 5a-f). Bacterial biomass increased after organic and mixed inputs in all the experiments except at $26^{\circ} \mathrm{N}$, where only the mixed addition resulted in an increase in bacterial biomass relative to the control, and at $3^{\circ} \mathrm{N}$, where bacterial biomass increased after the mixed or, to a lesser extent, the organic addition.

The relative contribution of vHNA bacteria to total bacterial biomass (vHNA/BB) increased beyond 0.5 after organic and mixed additions in all experiments (except for experiment at $26^{\circ} \mathrm{N}$ in which only the mixed addition resulted in a measurable positive response) (Fig. 5b).

The responses of bacterial production and bacterial respiration to nutrient additions were much stronger than those observed for primary production (Fig. 5c-d). After organic and mixed inputs, bacterial production increased in all experiments except at $26^{\circ} \mathrm{N}$, where only the mixed addition resulted in an increase relative to the control. BGE increased in the addition treatments relative to the control (Fig. 5e) following the pattern of bacterial production responses. Community respiration responses to nutrient additions were higher than those of primary production (Fig. $5 \mathrm{f}$ ). Bacterial respiration (i.e. ETS activity $<0.8 \mu \mathrm{m}$ ) and community respiration followed the same pattern as bacterial production (Fig. 5d, f). Bacterial respiration accounted for 20 to $40 \%$ of community respiration and this contribution did not significantly change among treatments and experiments (RMANOVA, $p>0.05$ ). Incubation time, experiment and addition treatment had a significant effect on all the heterotrophic variables $(p<0.01$, RMANOVA) except for the experiment effect on BGE. Significant stimulations 
$26^{\circ} \mathrm{N}$ $18^{\circ} \mathrm{N}$

$3{ }^{\circ} \mathrm{N}$

$12^{\circ} \mathrm{S}$ $29^{\circ} \mathrm{S}$
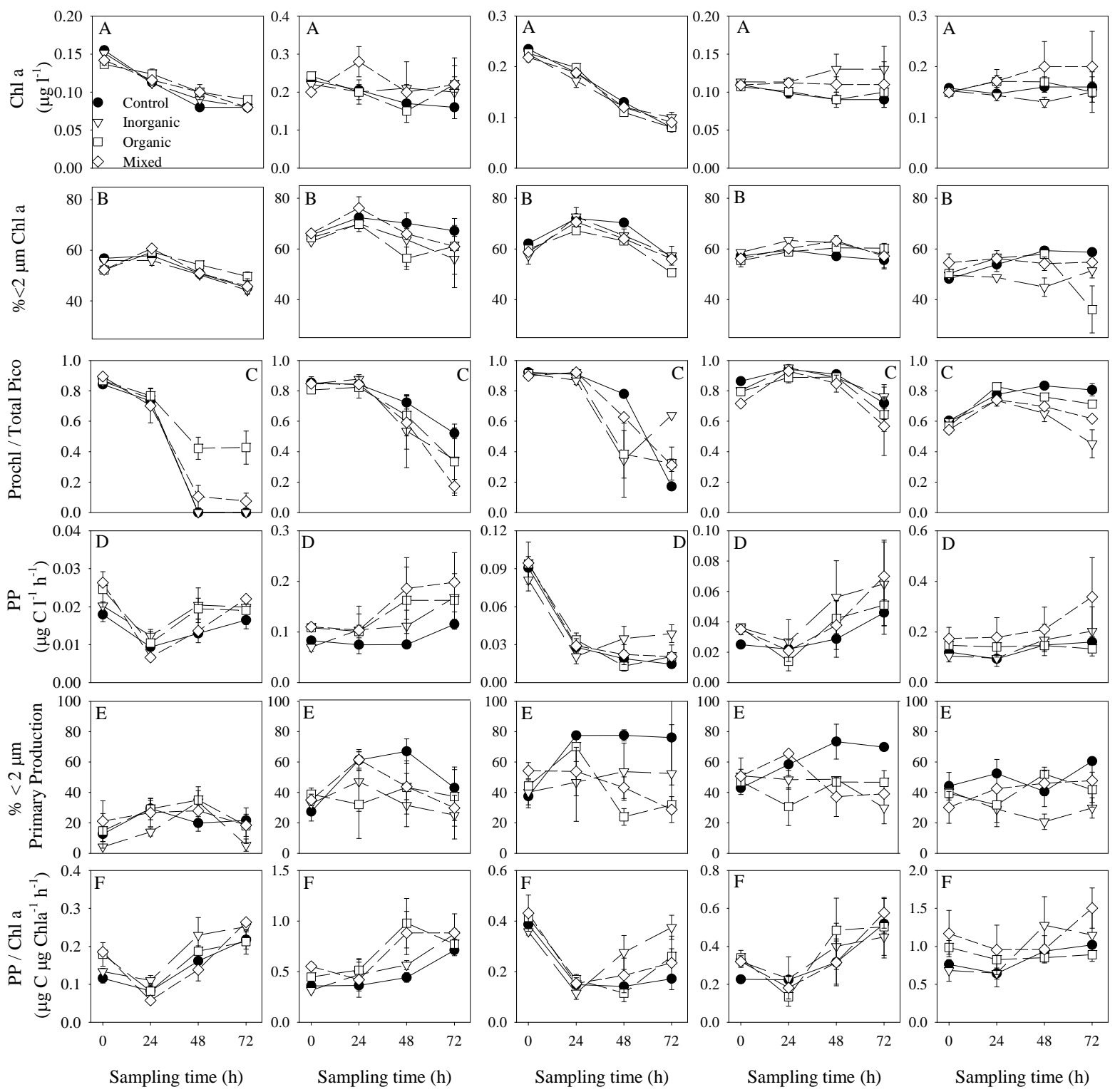

Fig. 3. Time course of the mean (A), chl $a$, chlorophyll $a\left(\mu \mathrm{g} 1^{-1}\right)$; (B), $\%<2 \mu \mathrm{m}$ chl $a$, percentage of $<2 \mu \mathrm{m}$ chlorophyll $a$; (C), Prochl: Total Pico., Prochlorococcus: Total picophytoplankton biomass ratio; (D), PP, total primary production $\left(\mu \mathrm{g} \mathrm{Cl}^{-1} \mathrm{~h}^{-1}\right) ;(\mathbf{E}), \%<2 \mu \mathrm{m} \mathrm{PP}$, percentage of $<2 \mu \mathrm{m}$ primary production; (F), PP/chl $a$, primary production to chl $a$ ratio, in the 5 experiments. Control, no addition; Inorganic, inorganic addition; Organic, organic addition; Mixed, mixed addition. Note that different scales were used. Error bars represent the standard error from two replicates; where error bars are not visible, they are smaller than the size of the symbol.

of all these variables were registered after organic and mixed additions (Bonferroni post-hoc test, Table 2). A significant interaction between the treatment and experiment factors, which indicates that the response to treatments varies among experiments, was also found for bacterial biomass, vHNA/BB ratio, bacterial production and community respiration (RMANOVA, $p<0.001$ ).
A north to south gradient in the magnitude of the heterotrophic responses was found when organic nutrients are added (Fig. 6a-f). Bacterial biomass and vHNA/BB increased up to 2.2 and 9.6-fold, respectively, after organic and mixed additions. The magnitude of response of bacterial production and bacterial respiration to the organic and mixed treatments was considerably higher (up to 58.8 and 11.4-fold increases, respectively) and followed a more evident north to south gradient than that of bacterial biomass. 
Table 2. Summary of the global effect of the different additions on biological variables (Bonferroni post hoc test): 0, no significant effect; + , significant effect $p<0.05 ;++$, significant effect $p<0.01$; +++ , significant effect $p<0.001 .+$, stimulation, -, inhibition. Chl $a$, chlorophyll $a$ concentration, \% Chl $a<2 \mu \mathrm{m}$, percentage of total chl $a$ in the fraction $<2 \mu \mathrm{m}$, Proch:Total Pico., Prochlorococcus: Total picophytoplankton biomass ratio, $\mathrm{BB}$, heterotrophic bacterial biomass, vHNA: BB, vHNA: Bacterial Biomass ratio, PP, primary production, $\% \mathrm{PP}<2 \mu \mathrm{m}$, percentage of total $\mathrm{PP}$ due to the fraction $<2 \mu \mathrm{m}, \mathrm{PP} / \mathrm{chl} a$, primary production to chlorophyll $a$ ratio, $\mathrm{BP}$, bacterial production, $\mathrm{BR}$, bacterial respiration (estimated from in vivo ETS activity due to the fraction $<0.8 \mu \mathrm{m}$ ), BGE, bacterial growth efficiency, CR, community respiration (estimated from total in vivo ETS activity)

\begin{tabular}{lccc}
\hline Variable & Inorganic & Organic & Mixed \\
\hline Chl $a$ & 0 & 0 & 0 \\
$\%$ Chl $a<2 \mu \mathrm{m}$ & 0 & 0 & 0 \\
Proch:Total Pico & 0 & 0 & 0 \\
BB & 0 & ++ & +++ \\
vHNA:BB & 0 & +++ & +++ \\
PP & 0 & 0 & 0 \\
$\%$ PP $<2 \mu \mathrm{m}$ & - & 0 & 0 \\
PP/chl $a$ & 0 & 0 & 0 \\
BP & 0 & +++ & +++ \\
BR & 0 & +++ & +++ \\
BGE & 0 & ++ & ++ \\
CR & 0 & +++ & +++ \\
\hline
\end{tabular}

BGE increases ranged from 1.2 to 2.5 -fold when organic nutrients were added and were higher in the southern experiments (Fig. 6f). Higher community respiration responses were also registered at the southern stations (up to 8 and 8.6-fold increases for experiments at $12^{\circ} \mathrm{S}$ and $29^{\circ} \mathrm{S}$ respectively) although the maximum value was registered in the mixed treatment at the northernmost experiment (12.7-fold).

\section{Discussion}

The response of the autotrophic and heterotrophic microbial compartments to the different additions assessed in this investigation varied greatly, both in direction and magnitude, as a function of latitude and experimental treatment, suggesting that different processes are likely to control phytoplankton and bacterial dynamics in the five sampled locations. Overall, the responses of the heterotrophic compartment were clearly larger than those of autotrophs, which barely responded to the added nutrients.

\subsection{Responses of autotrophic communities}

The phytoplankton responses to nutrient amendments were small when compared to those of heterotrophic bacteria, although different patterns among the five experiments were found (Figs. 3 and 4).
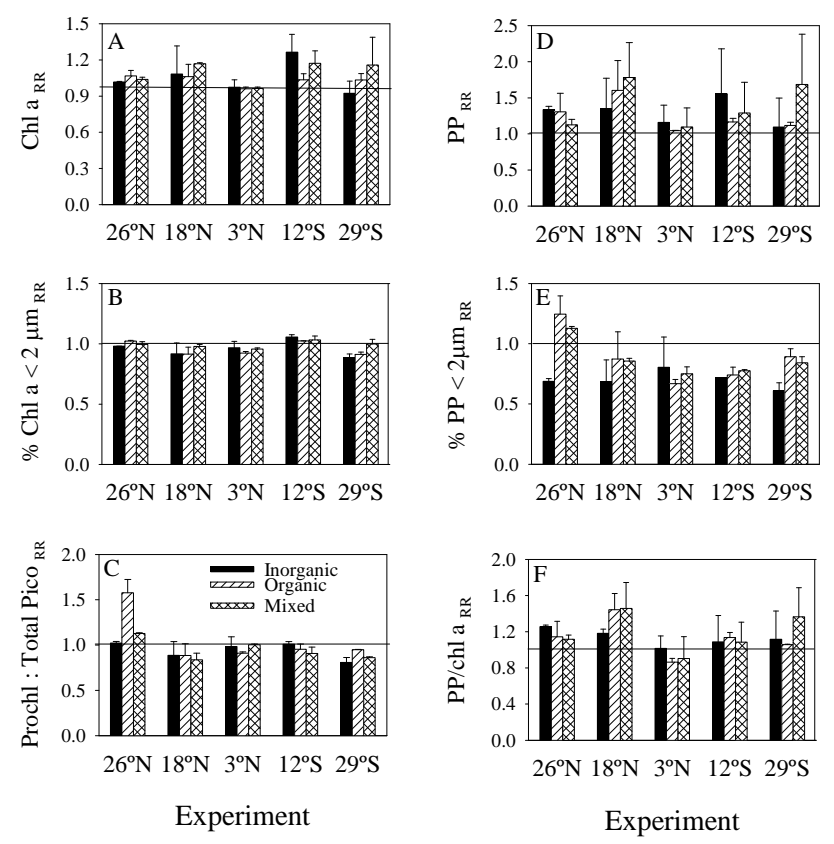

Fig. 4. Response ratios of (A), total chlorophyll $a$ concentration (Chl $\left.a_{\mathrm{RR}}\right)$; (B), percentage of $<2 \mu \mathrm{m}$ chlorophyll $a$ (\%Chl $a<$ $\left.2 \mu m_{\mathrm{RR}}\right)$; (C), Prochlorococcus: Total picophytoplankton biomass ratio (Proch:Total pico ${ }_{\mathrm{RR}}$ ); (D), primary production $\left(\mathrm{PP}_{\mathrm{RR}}\right)$; $(\mathbf{E})$, percentage of $<2 \mu \mathrm{m}$ primary production $\left(\% \mathrm{PP}<2 \mu m_{\mathrm{RR}}\right)$; $(\mathbf{F})$, primary production to chl $a$ ratio ( $\left.\mathrm{PP} / \mathrm{chl} a_{\mathrm{RR}}\right)$, in microcosms amended with inorganic, organic and mixed nutrients, expressed as a ratio of the time-integrated value relative to the time-integrated value in the control microcosms (or time averaged in the case of standing stocks). Inorganic, inorganic addition; Organic, organic addition; Mixed, mixed addition. Error bars represent the standard error from two replicates. The horizontal line in each graph represents 1 relative to 1 (no change) relative to control. Note that different scales were used.

Phytoplankton communities from $26^{\circ} \mathrm{N}$ and $3^{\circ} \mathrm{N}$ experienced a decrease in biomass during the experiment (Fig. 3a), a response that has been observed during previous in vitro experiments in oligotrophic waters (Caron et al., 2000; Lignell et al., 2003; Davey et al., 2008). We do not have a definitive explanation for the decrease of chl $a$ at $26^{\circ} \mathrm{N}$ and $3^{\circ} \mathrm{N}$ (Fig. 3a). On one hand, the parallel decrease in primary production and $\mathrm{PP} / \mathrm{chl} a$ ratio during the first $24 \mathrm{~h}$ incubation, especially at $3^{\circ} \mathrm{N}$,would suggest a poor physiological condition of the phytoplankton assemblages, limitation by micronutrients not studied in this investigation or differential susceptibility of autotrophic communities to the methodological procedure. On the other hand, the $\mathrm{PP} / \mathrm{chl} a$ ratio increased after the first incubation day (Fig. 3f), which would suggest that the decrease of chl $a$ concentration was caused by top-down control of phytoplankton at these stations. This explanation is reinforced by the higher abundance of heterotrophic flagellates at these two sites (up to 2-fold relative to the rest, data not shown). The pronounced decreases in Prochl:Total Pico ratio with incubation time observed in 
northern experiments (Fig. 3c) suggests either a high grazing pressure over this group or a high susceptibility of Prochlorococcus to handling (Partensky et al., 1999). Similar results have been previously reported by Herut et al. (2005), Davey et al. (2008) and Paytan et al. (2009).

Primary production moderately increased (up to 1.8 -fold) after inorganic and mixed additions. Higher responses were found by Mills et al. (2004) and Moore et al. (2006, 2008) in the subtropical North Atlantic after inorganic (N and $\mathrm{P}$ ) nutrient additions, possibly due to the higher final concentrations of the nutrients added ( 2 and 4 -fold higher for $\mathrm{N}$ and $\mathrm{P}$, respectively).

Enhanced primary production was paralleled by changes in the size distribution of phytoplankton populations. The decrease of picophytoplankton contribution to total primary production observed when inorganic nutrient additions were performed (Figs. 3e and 4e), is likely related to a higher growth potential of $>2 \mu \mathrm{m}$ phytoplankton cells, known to be highly efficient when nutrients are available (Thingstad and Sakshaug, 1990; Agawin et al., 2000; Cermeño et al., 2005). At $26^{\circ} \mathrm{N}$ the contribution of $<2 \mu \mathrm{m}$ cells to primary production increased in the organic treatments relative to the control, possibly associated with the presence of mixotrophic picophytoplankton (Figs. 3e and 4e).

\subsection{Responses of heterotrophic communities}

Heterotrophic microbial responses to the additions significantly differed among experiments (RMANOVA, $p<0.05$ ), being always larger than autotrophic responses. Bacterial biomass and activity were stimulated by organic additions and differences among experiments were observed. Heterotrophic bacterial metabolic rates (bacterial production and bacterial respiration) responded considerably more than bacterial biomass, likely related to the widely reported strong top-down control (i.e. predation) on microbial populations in these oligotrophic environments (Weisse and ScheffelMöser, 1991; Zubkov et al., 2000; Jürgens and Massana, 2008). Bacterial biomass and bacterial production values measured in this work after nutrient additions are within the range of in situ values reported for the central Atlantic Ocean (Zubkov et al., 1998; Morán et al., 2004; Gasol et al., 2009), which support the adequacy of the chosen concentrations of added nutrients in the experimental design adopted in this study.

Bacterial biomass and bacterial production were stimulated by organic nutrients in all the experiments but only responded to the mixed addition of inorganic and organic nutrients at $26^{\circ} \mathrm{N}$ (Figs. 5a, c and 6a, c). In the experiment performed at $3^{\circ} \mathrm{N}$, the additional inorganic nutrients supplied allowed bacteria to utilize more organic matter in the mixed treatment than in the organic treatment. It has been demonstrated that inorganic nutrient limitation prevents bacteria to utilize organic matter and contributes to DOC accumulation in the upper water column (Rivkin and Anderson
1997; Thingstad et al., 1997; Tanaka et al., 2009). Considering that our organic addition includes $\mathrm{N}$ but not $\mathrm{P}$, the bacterial responses observed at $26^{\circ} \mathrm{N}$ and $3^{\circ} \mathrm{N}$ are most likely explained by the low phosphorous availability previously reported for the North Atlantic (Fanning, 1992; Mather et al., 2008). Accordingly, bacterial biomass and bacterial production responses to organic additions were much higher in the southern than in the northern stations, possibly associated to the higher inorganic phosphorous availability in the South than in the North Atlantic Subtropical Gyre (Mather et al., 2008, Table 1).

The magnitude of the bacterial biomass and bacterial production responses to nutrient additions (Fig. 6) is in agreement with previous addition experiments in the Sargasso Sea (Carlson et al., 2002). By contrast, other addition experiments in the North Atlantic (Mills et al., 2008) registered considerably higher responses, both in bacterial biomass and bacterial production, to mixed (inorganic $\mathrm{N}$ and $\mathrm{P}$, and DOC) additions than the ones presented in the present work. It is worth mentioning that in that study the final concentrations of DOC, inorganic $\mathrm{N}$ and inorganic $\mathrm{P}$ added were 10,2 and 4-fold higher than the final concentrations tested in the present study. Furthermore, the N:P ratios of the additions performed in those investigations were below Redfield ratio (i.e. $\mathrm{N}: \mathrm{P}=10$ ), which implies an extra $\mathrm{P}$ relative to $\mathrm{N}$ supply. Interestingly the magnitude of bacterial response to our organic and mixed additions was similar to that previously observed after experimental Saharan surface soils additions (Bonnet et al., 2005; Pulido-Villena et al., 2008), collectedaerosols additions (Herut et al., 2005;) or after real dust deposition events (Herut et al., 2005; Pulido-Villena et al., 2008).

vHNA bacteria, equivalent to the HNA2 group described by Fernández et al. (2008) in the NE Atlantic Ocean, accounted for a considerable fraction of the total bacterial standing stock when bacterial biomass and bacterial production enhancements were registered (Figs. $5 b$ and $6 b$ ), an observation consistent with the role of vHNA as rapid responders, benefiting from high inorganic $(\mathrm{N}, \mathrm{P})$ and organic nutrient concentrations (Jacquet et al., 2002).

Only a few nutrient addition studies have included microbial respiration as response variable. Alonso-Sáez et al. (2007) found that bacterial respiration in the North Atlantic Ocean was generally unaffected by inorganic (nitrate and phosphate) or by organic (glucose and acetate) nutrients. By contrast, the observed increases of bacterial and community respiration in the present work (1.3 to 12.7 -fold) are comparable to the increases in respiration associated with experimental Saharan surface soils additions (Pulido-Villena et al., 2008; E. Marañón et al., 2010) with collected-aerosols additions (Marañón et al., 2010) and with natural dust depositions events (Pulido-Villena et al., 2008).

BGE increased after organic additions in all the experiments and the magnitude of the increases was higher in the southern experiments (up to 2.5 -fold). The response pattern of BGE suggested a more efficient utilization of the 
$26^{\circ} \mathrm{N}$
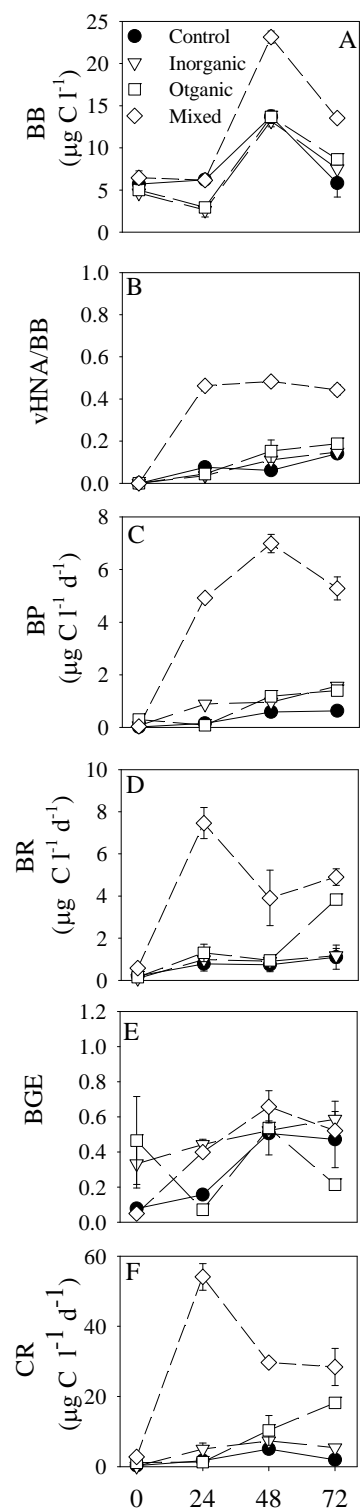

Sampling time (h) $18^{\circ} \mathrm{N}$
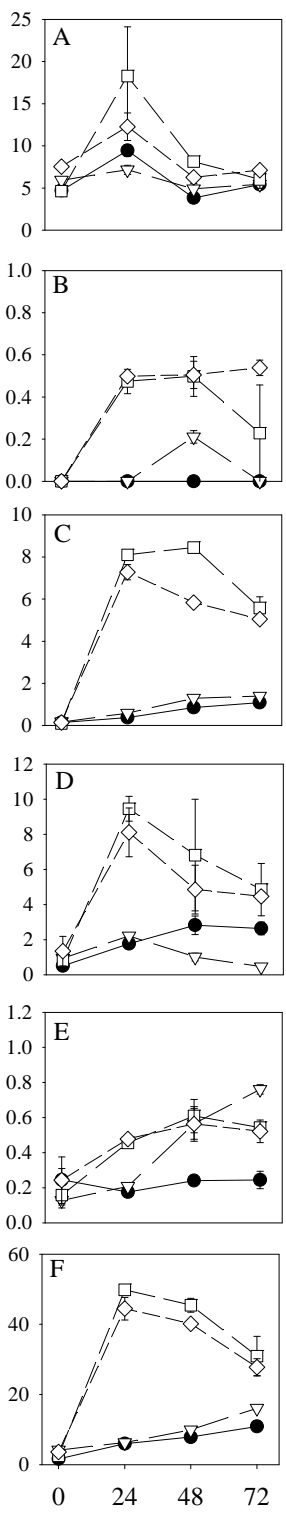

Sampling time (h) $3^{\circ} \mathrm{N}$
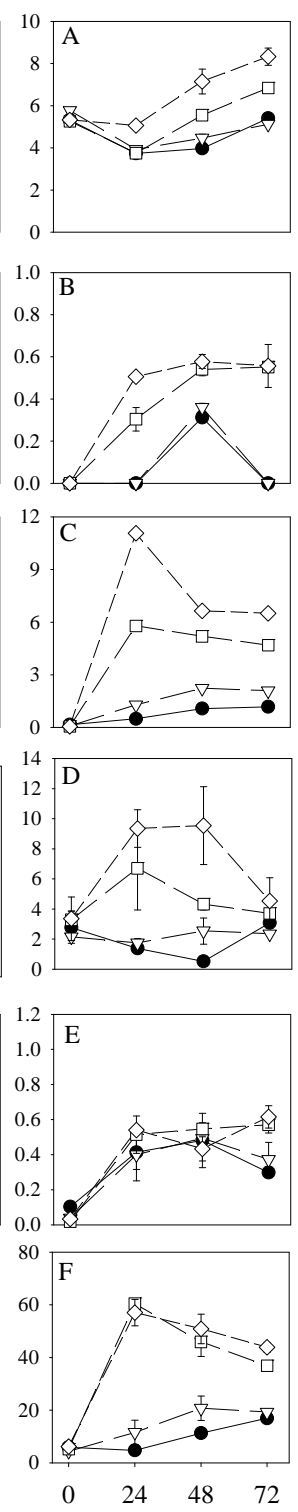

Sampling time (h) $12^{\circ} \mathrm{S}$

$29^{\circ} \mathrm{S}$
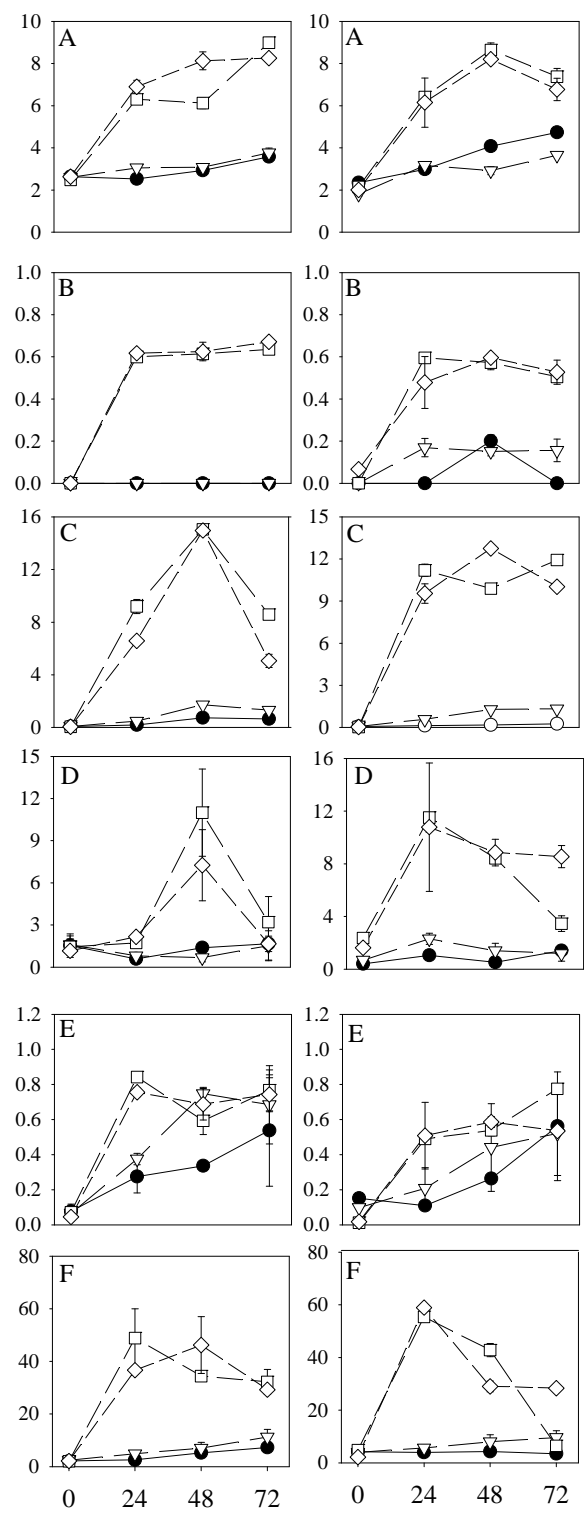

Sampling time (h)

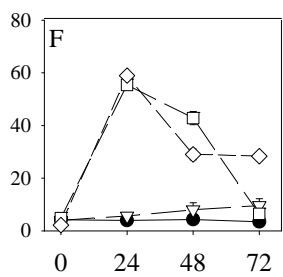

Sampling time (h)

Fig. 5. Time course of the mean (A), BB, bacterial biomass $\left(\mu \mathrm{gCl}^{-1}\right)$; (B), vHNA:BB, vHNA: Bacterial Biomass ratio; (C), BP, bacterial

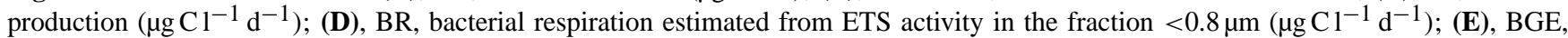
bacterial growth efficiency; (F) CR, community respiration estimated from total ETS activity $\left(\mu \mathrm{g} \mathrm{Cl}{ }^{-1} \mathrm{~d}^{-1}\right)$, in the 5 experiments. Control, no addition; Inorganic, inorganic addition; Organic, organic addition; Mixed, mixed addition. Note that different scales were used. Error bars represent the standard error from two replicates; where error bars are not visible, they are smaller than the size of the symbol.

added organic carbon by heterotrophic bacteria (Zweifel et al., 1993; Pomeroy et al, 1995; del Giorgio and Cole, 2000) in the south than in the north (Fig. 6e), a latitudinal pattern likely related to the aforementioned higher availability of phosphate in the southern stations. A higher P-availability would explain a higher bacterial growth efficiency (BGE), and also a higher accumulation of bacterial biomass (Fig. 6a), given the relatively elevated P-content of bacterial biomass
(Norland et al. 1995). Actually, the lowest BGE response was measured in the organic treatment at $26^{\circ} \mathrm{N}$ suggesting an extreme $\mathrm{P}$ deficiency at this site. The biogeochemical implications of the BGE enhancement estimated for the south Atlantic would be an increase of the potential carbon export as a consequence of a higher carbon flow through the microbial food web (Azam et al., 1983; del Giorgio and Cole, 2000; Ducklow, 2000). 

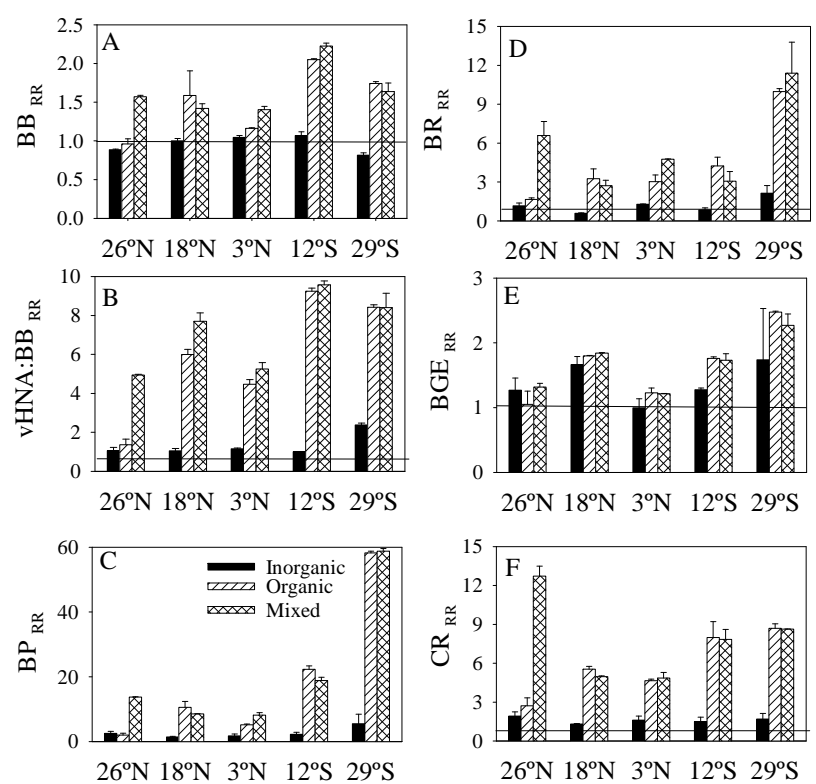

Experiment

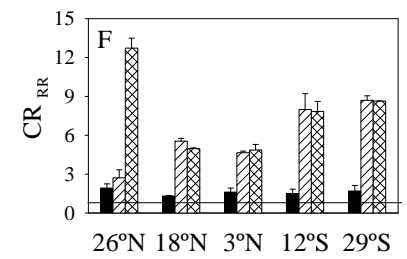

Experiment

Fig. 6. Response ratios of (A), total bacterial biomass $\left(\mathrm{BB}_{\mathrm{RR}}\right)$; (B), vHNA to Bacterial Biomass ratio (vHNA:BBRR); (C), bacterial production $\left(\mathrm{BP}_{\mathrm{RR}}\right)$; $(\mathbf{D})$, bacterial respiration $\left(\mathrm{BR}_{\mathrm{RR}}\right) ;(\mathbf{E})$, bacterial growth efficiency $\left(\mathrm{BGE}_{\mathrm{RR}}\right)$; $(\mathbf{F})$ community respiration $\left(\mathrm{CR}_{\mathrm{RR}}\right)$, in microcosms amended with inorganic, organic and mixed nutrients, expressed as a ratio of the time-integrated value relative to the time-integrated value in the control microcosms (or time averaged in the case of standing stocks). Inorganic, inorganic addition; Organic, organic addition; Mixed, mixed addition. Error bars represent the standard error from two replicates The horizontal line in each graph represents 1 relative to 1 (no change) relative to control. Note that different scales were used.

\section{Heterotrophic vs. autotrophic responses}

Bacterioplankton responses when both inorganic and organic nutrients were supplied were much higher than phytoplankton responses, thus potentially driving the microbial community towards heterotrophy. In oligotrophic environments, if organic carbon is readily available, heterotrophic bacteria are expected to be more efficient in the uptake of inorganic nutrients than phytoplankton, due to their higher surface area to volume ratio (Cotner and Bidanda, 2002). Furthermore, heterotrophic bacteria requirements of inorganic nutrients are larger than those of phytoplankton due to the lower C:N and $\mathrm{C}: \mathrm{P}$ ratios of bacteria as compared to phytoplankton (Cotner and Bidanda, 2002).

Community respiration enhancements after organic and mixed treatments were always higher than those of primary production. This implies a decrease in the photosynthesis to respiration ratio that was more evident in the South than in the North Atlantic.

The predominantly heterotrophic response consistently observed after mixed additions agree with previous nutri-

ent addition experiments in coastal zones (Joint et al., 2002) and also with observations obtained after Saharan surface soils and after collected aerosols addition experiments in oligotrophic waters (Herut et al., 2005; Reche et al., 2009; Marañón et al., 2010). These last studies found a globally higher (up to 8-fold) heterotrophic response compared to phytoplankton response associated with realistic atmospheric inputs. Given the observed limited response of bacteria to our inorganic additions, we speculate that a predominantly heterotrophic response to atmospheric deposition might be at least partially explained by inputs of readily available organic matter. Indeed, several works have shown significant amounts of dissolved organic nitrogen and carbon associated with atmospheric deposition (e.g. Cornell et al., 1995; Pulido-Villena et al., 2008).

Our findings might be relevant in the context of the recently published projections of future matter inputs into the oceans (Dentener 2006; Duce 2008). Increasing amounts of organic matter of atmospheric origin are expected to be entering the open ocean in the next decades. A significant fraction of this organic matter might be readily available for microbial utilization (Seitzinger and Sanders, 1999). Our results suggest that the ultimate fate of this organic matter, i.e., the relative importance of accumulation in the water column, conversion to potentially exportable microbial biomass or remineralization to $\mathrm{CO}_{2}$, will depend on the initial environmental and biological conditions of the oceanic region where deposition occurs. Differences between North and South Atlantic microbial plankton community responses to the matter inputs in this investigation appeared to be related to the latitudinal gradient of $\mathrm{P}$ availability. The apparently higher efficiency of organic matter utilization by bacteria in the South than in the North Atlantic would ultimately result in a comparatively higher potential for carbon export to deep waters. On the other hand, the expected decrease in the photosynthesis to respiration ratio in the upper tropical and subtropical Atlantic associated with organic matter inputs is likely to affect the $\mathrm{CO}_{2}$ exchange between the ocean and the atmosphere.

Acknowledgements. We thank all the people involved in the project TRYNITROP who helped with the preparation and sampling of the experiments. We also would like to thank J. Escánez and J. F. Domínguez for the nutrient analyses and L. Díaz-Pérez for her help with flow cytometry measurements. We thank the officers and crew of the $R / V$ Hesperides, as well as the staff of the Technical Support Unit (UTM), for their support during the work at sea. This research was supported by the MEC contract TRYNITROP (CTM2004-05174-C02) and the Xunta de Galicia AddEX contract (PGIDIT06PXIB312222PR). S.M-G. was funded by a F. P. U. MEC fellowship. E. T. was founded by a Juan de la Cierva and a Ramón y Cajal-MEC contract.

Edited by: G. Herndl 


\section{References}

Agawin, N. S. R., Duarte, C. M., and Agustí, S.: Nutrient and temperature control of the contribution of picoplankton to phytoplankton biomass and production, Limnol. Oceanogr., 45, 591600, 2000.

Ammerman, J. W., Hood, R. R., Case, D. A., and Cotner, J. B.: Phosphorous deficiency in the Atlantic: An emerging paradigm in oceanography, Eco Trans AGU 84, 165-170, 2003.

Alonso-Sáez, L., Gasol, J. M., Arístegui, J., Vilas, J. C., Vaqué, D., Duarte, C. M., and Agustí, S.: Large-scale variability in surface bacterial carbon demandand growth efficiency in the subtropical northeast Atlantic Ocean, Limnol. Oceanogr., 52, 533-546, 2007.

Arrigo, K. R.: Marine microorganisms and global nutrientcycles, Nature, 437, 349-355, 2005.

Azam, F., Fenchel, T., Field, J. G., Gray, J. S., Meyer-Rail, L. A., and Thingstad, F.: The ecological role of water-column microbes in the sea, Mar. Ecol. Prog.-Ser., 10, 257-263, 1983.

Baker, A. R., Weston, K., Kelly, S. D., Voss, M., Streu, P, and Cape, J. N.: Dry and wet deposition of nutrients from the tropical Atlantic atmosphere: Links to primary productivity and nitrogen fixation, Deep-Sea Res. Pt. I, 54, 1704-1720, 2007.

Bonnet, S., Guieu, C., Chiaverini, J., Ras, J., and Stock, A.: Effect of atmospheric nutrients on the autotrophic communities in a low nutrient, low chlorophyll syatem, Limnol. Oceanogr., 50, 18101819, 2005.

Calvo-Díaz, A. and Morán, X. A. G.: Seasonal dynamics of picoplankton in shelf waters of the southern Bay of Biscay, Aquat. Microb. Ecol., 42, 159-174, 2006.

Calvo-Díaz, A. and Morán, X. A. G.: Empirical leucine-to-carbon conversión factors for estimating heterotrophic bacterial production: seasonality and predictability in a temperate coastal ecosystem, Appl. Environ. Microbiol., 75, 3216-3221, 2009.

Carlson, C. A., Giovannoni, S. J., Hansell, D. A., Goldberg, S. J., Parsons, R., Otero, M. P., Vergin, K., and Wheeler, B. R.: Effect of nutrient amendments on bacterioplankton production, community structure, and DOC utilization in the northwestern Sargasso Sea, Aquat. Microb. Ecol., 30, 19-36, 2002.

Caron, D. A., Lim, E. L., Sanders, R. W., Dennett, M. R., and Berninger, U. G.: Responses of bacterioplankton and phytoplankton to organic carbon and inorganic nutrient additions in contrasting oceanic ecosystems, Aquat. Microb. Ecol., 22, 176$184,2000$.

Cermeño, P., Marañón, E., Rodríguez, J., and Fernández, E.: Largesized phytoplankton sustain higher carbon-specific photosynthesis than smaller cells in a coastal eutrophic ecosystem, Mar. Ecol. Prog.-Ser., 297, 51-60, 2005.

Church, M. J., Hutchins, D. A., and Ducklow, H. W.: Limitation of bacterial growth by dissolved organic matter and iron in the Southern Ocean, Appl. Environ. Microbiol., 66, 455-466, 2000.

Church, M. J.: Resource control of bacterial dynamics in the sea, in: Microbial Ecology of theOceans (2nd edition), edited by: Kirchman, D. L., Wiley-Liss, New York, 335-382, $2008 .$.

Cornell, S., Rendell, A, and Jickells, T.: Atmospheric inputs of dissolved organic nitrogen to the oceans, Nature, 376, 243-246, 1995.

Cotner, J. B. and Biddanda, B. A.: Small players, large role: Microbial influence on biogeochemical processes in pelagic aquatic ecosystems, Ecosystems, 5, 105-121, 2002.
Cullen, J. J., Yang, X., and Macintyre, H. L.: Nutrient limitation of marine photosynthesis, in: Primary Productivity and Biogeochemical Cycles in the Sea, edited by: Falkowski, P. G. and Woodhead, A., Plenum, New York, 69-88, 1992.

Davey, M., Tarran, G. A., Mills, M. M., Ridame, C., Geider, R. J., and LaRoche, J.: Nutrient limitation of picophytoplankton photosynthesis and growth in the tropical North Atlantic, Limnol. Oceanogr., 53, 1722-1733, 2008.

Davidson, K., Gilpin, L. C., Hart, M. C., Foilland, E., Mitchell, E., Álvarez-Calleja, I., Laurent, C., Miller, A. E. J., and Leakey, J. G.: The influence of the balance of inorganic and organic nitrogen on the trophic dynamics of microbial food webs, Limnol. Oceanogr., 52, 2147-2163, 2007.

del Giorgio, P. A. and Cole, J. J.: Bacterial energetics and growth efficiency, in: MicrobialEcology of the Oceans (1st edition), edited by: Kirchman, D. L., Wiley-Liss, New York, 289-326, 2000.

Dentener, F., Drevet, J., Lamarque, J. F., Bey, I., Eickhout, B., Fiore, A. M., Hauglustaine, D., Horowitz, L. W., Krol, M., Kulshrestha, U. C., Lawrence, M., Galy-Lacaux, C., Rast, S., Shindell,D., Stevenson, D., Van Noije, T., Atherton, C., Bell, N., Bergman, D., Butler, T., Cofala, J., Collins, B., Doherty, R., Ellingsen, K., Galloway, J., Gauss, M., Montanaro, V., Müller, F., Pitari, G., Rodriguez, J., Sanderson, M.,. Solmon, F., Strahan, S., Schultz, M., Sudo, K., Szopa, S., and Wild, O.: Nitrogen and sulfur deposition on regional scales: a multimodelevaluation, Global Biogeochem. Cy., 20, GB4003, doi:10.1029/2005GB002672, 2006.

Duce, R. A., LaRoche, J., Altieri, K., Arrigo, K. R., Baker, A. R., Capone, D. G., Cornell, S., Dentener, F., Galloway, J., Ganeshram, R. S., Geider, R. J., Jickells, T., Kuypers, M. M., Langlois, R., Liss, P. S., Liu, S. M., Middelburg, J. J., Moore, C. M., Nickovic, S., Oschlies, A., Pedersen, T., Prospero, J., Schlitzer, R., Seitzinger, S., Sorensen, L. L., Uematsu, M., Ulloa, O., Voss, M., Ward, B., and Zamora, L.: Impacts of atmospheric anthropogenic nitrogen on the open ocean, Science, 320 , 893-897, 2008.

Ducklow, H.: Bacterial production and biomass in the oceans, in: Microbial Ecology of theOceans (1st edition), edited by: Kirchman, D. L., Wiley-Liss, New York, 85-120, 2000.

Falkowski, P. G.: Evolution of the nitrogen cycle and its influence on the biological sequestration of $\mathrm{CO}_{2}$ in the ocean, Nature, 387, 272-275, 1997.

Fanning, K. A.: Nutrient provinces in the Sea: Concentration Ratios, Reaction Rate Ratios, and Ideal Covariation, J. Geophys. Res., 97, 5693-5712, 1992.

Faul, F., Erdfelder, E., Lang, A. G., and Buchner, A.: G*Power 3: A flexible statistical power analysis for the social, behavioural, and biomedical sciences, Behav. Res. Methods, 39, 175-191, 2007.

Gasol, J. M. and del Giorgio, P. A.: Using flow citometry for counting natural planktonic bacteria and understanding the structure of planktonic bacterial communities, Sci. Mar., 64, 197-224, 2000.

Gasol, J. M., Vázquez-Dominguez, E., Vaqué, D., Agustí, S., and Duarte, C. M.: Bacterial activity and diffusive nutrient supply in the oligotrophic Central Atlantic Ocean, Aquat. Microb. Ecol., 56, 1-12, 2009.

Graziano, L. M., Geider, R. J., Li, W. K. W., and Olaizola, M.: Nitrogen limitation of North Atlantic phytoplankton: Analysis of physiological condition in nutrient enrichment experiments, Aquat. Microb. Ecol., 11, 53-64, 1996.

Gundersen, K., Heldal, M., Norland, S., Purdie, D. A., and Knap, 
A. N.: Elemental C, N, and P cell content of individual bacteria collected at the Bermuda Atlantic Time-series Study (BATS) site, Limnol. Oceanogr., 47, 1525-1530, 2002.

Herut, B., Zohary, T., Krom, M. D., Mantourad, R. F. C., Pitta, P., Psarra, S., Rassoulzadeganf, F., Tanaka, T., and Thingstadg, T. F.: Response of Mediterranean surface water to Saharan dust: Onboard microcosm experiment and field observations, Deep-Sea Res. Pt. II, 52, 3024-3040, 2005.

Jacquet, S., Havskum, H., Thingstad, T. F., and Vaulot, D.: Effects of inorganic and organic nutrient addition on a coastal microbial community (Isefjord, Denmark), Mar. Ecol. Prog.-Ser., 228, 314, 2002.

Joint, I., Henriksen, P., Fonnes, G. A., Bourne, D., Thingstad, T. F., and Riemann, B.: Competition for inorganic nutrients between phytoplankton and bacterioplankton in nutrient manipulated mesocosms, Aquat. Microb. Ecol., 29, 145-159, 2002.

Jurado, E., Dachs, J., Duarte, C. M., and Simó, R.: Atmospheric deposition of organic and black carbon to the global oceans, Atmos. Environ., 4, 7931-7939, 2008.

Jürgens, K. and Massana, R.: Protistan grazing on marine bacterioplankton, in: Microbial Ecology of the Oceans (2nd edition), edited by: Kirchman, D. L., Wiley-Liss, New York, 383-441, 2008.

Kerouel, R. and Aminot, A. Fluorometric determination of ammonia in sea and estuarine waters by direct segmented flow analysis, Mar. Chem., 57, 265-275, 1997.

Kirchman, D., K'nees, E., and Hodson, R.: Leucine incorporation and its potential as a mesure of protein synthesis by bacteria in natural aquatic systems, Appl. Environ. Microbiol., 49, 599-607, 1985.

Lignell, R., Seppälä, J., Kuuppo, P., Tamminen, T., Andersen, T.,and Gismervik, I.: Beyond bulk properties: Responses of coastal summer plankton communities to nutrient enrichment in the northern Baltic Sea, Limnol. Oceanogr., 48, 189-209, 2003.

Mace, K. A., Kubilay, N., and Duce, R. A.: Organic nitrogen in rain and aerosol in the easternMediterranean atmosphere: An association with atmospheric dust, J. Geophys. Res.-Atmos., 108, 4320, doi:10.1029/2002JD002997, 2003.

Marañón, E., Holligan, P. M., Barciela, R., González, N., Mouriño, B., Pazó, M. J., and Varela, M.: Patterns of phytoplankton size structure and productivity in contrasting open-ocean environments, Mar. Ecol. Prog.-Ser., 216, 43-56, 2001.

Marañón, E., Behrenfeld, M. J., Gonzalez, N., Mourino, B., and Zubkov, M. V.: High variability of primary production in oligotrophic waters of the Atlantic Ocean: uncoupling from phytoplankton biomass and size structure, Mar. Ecol. Prog.-Ser., 257, 1-11, 2003.

Marañón, E., Fernández, A., Huete-Ortega, M., MouriñoCarballido, B., Cermeño, P., Chouciño, P., Martínez-García, S., Teira, E., Fernández, E., Calvo-Díaz, A., Morán, X. A. G., Bode, A., Moreno-Ostos, E., Varela, M. M., Patey, M., and Achterberg, E. P.: The degree of oligotrophy controls the response of microbial plankton to saharan dust, submitted to Limnol. Oceangr., 2010.

Martínez-García, S., Fernández, E., Aranguren-Gassis, M., and Teira, E.: In vivo electron transport system activity: a method to estimate respiration in marine microbial planktonic communities, Limnol Oceanogr.-Meth., 7, 459-469, 2009.

Mather, R. L., Reynolds, S. E., Wolff, G. A., Williams, R. G.,
Torres-Valdés, S., Woodward, E. M. S., Landolfi, A., Pan, X., Sanders, R., and Achterberg, E. P.: Phosphorus cycling in the North and South Atlantic Ocean subtropical gyres, Nat. Geosci., 1, 439-443, 2008.

Mills, M. M., Ridame, C., Davey, M., La Roche, J., and Geider, R. J.: Iron and phosphorus co-limit nitrogen fixation in the eastern tropical North Atlantic, Nature, 429, 292-294, 2004.

Mills, M. M., Moore, C. M., Langlois, R., Milne, A., Achterberg, E., Nachtigall, K., Lochte, K., Geider, R. J., and La Roche, J.: Nitrogen and phosphorus co-limitation of bacterial productivity and growth in the oligotrophic subtropical North Atlantic, Limnol. Oceanogr., 53, 824-834, 2008.

Moore, C. M., Mills, M. M., Milnes, A., Langlois, R., Achterberg, E. P., Lochte, K., Geider, R. J., and LaRoche, J.: Iron limits primary productivity during spring bloom development in the central North Atlantic, Glob. Change Biol., 12, 626-634, 2006.

Moore, C. M., Mills, M. M., Langlois, R., Milne, A., Achterberg, E. P., La Roche, J., and Geider, R. J.: Relative influence of nitrogen and phosphorus availability on phytoplankton physiology and productivity in the oligotrophic sub-tropical North Atlantic Ocean, Limnol. Oceanogr., 53, 291-305, 2008.

Morán, X. A. G., Fernández, E., and Pérez, V.: Size-fractionated primary production, bacterial production and net community production in subtropical and tropical domains of the oligotrophic NE Atlantic in autumn, Mar. Ecol. Prog.-Ser., 274, 17-29, 2004.

Norland, S., Fagerbakke, K. M., and Heldal, M.: Light Element Analysis of Individula Bacteria by X-ray Microanalysis, Appl. Environ. Microbiol., 61, 1357-1362, 1995.

Paerl, H. W.: Coastal eutrophication and harmful algal blooms: Importance of atmospheric deposition and groundwater as "new" nitrogen and other nutrient sources, Limnol. Oceanogr., 42, 1154-1165, 1997.

Partensky, F., Hess, W. R., and Vaulot, D.: Prochlorococcus, a marine photosynthetic prokaryote of global significance, Microbial Molecular Biology Reviews 63, 106-127, 1999.

Paytan, A., Mackey, K. R. M., Cheng, Y., Lima, I. D., Doney, S. C., Mahowald, N., Labiosa, R., and Post, A. F.: Toxicity of atmospheric aerosols on marine phytoplankton. Proceedings of the National Academy of Sciences of the United States of America 106, 4601-4605, 2009.

Peierls, B. L. and Paerl, H. W.: Bioavailability of atmospheric organic nitrogen deposition to coastal phytoplankton, Limnol. Oceanogr., 42, 1819-1823, 1997.

Pomeroy, R., Sheldon, J. E., Sheldon, W. M., and Peters, F.: Limits to growth and respiration of bacterioplankton in the Gulf of Mexico, Mar. Ecol. Prog.-Ser., 117, 259-268, 1995.

Pulido-Villena, E., Wagener, T., and Guieu, C.: Bacterial response to dust pulses in theWesternMediterranean: implications for carbon cycling in the oligotrophic ocean, Global Biogeochem. Сy., 22, GB1020, doi:10.1029/2007GB003091, 2008.

Raimbault, P., Slawyk, G., Coste, B., and Fry, J.: Feasibility of Using an Automated Colorimetric Procedure for the Determination of Seawater Nitrate in the 0 to $100 \mathrm{~nm}$ Range - Examples from Field and Culture, Mar. Biol., 104, 347-351, 1990.

Reche, I., Ortega-Retuerta, E., Romera, O., Pulido-Villena, E., Morales-Baquero, R., and Casamayor, E.: Effect of Saharan dust inputs on bacterial activity and community composition in Mediterranean lakes and reservoirs, Limnol. Oceanogr., 54, 869879, 2009. 
Rivkin, R. B. and Anderson, M. R.: Inorganic nutrient limitation of oceanic bacterioplankton, Limnol. Oceanogr., 42, 730-740, 1997.

Robinson, C.: Heterotrophic bacterial respiration, in: Microbial Ecology of the Oceans (2nd edition), edited by: Kirchman, D. L., Wiley-Liss, New York, 299-336, 2008.

Saito, M. A., Goepfert, T. J., and Ritt, J. T.: Some thoughts on the concept of colimitation: Three definitions and the importance of bioavailability, Limnol. Oceanogr., 53, 276-290, 2008.

Scheiner, S. M. and Gurevitch, J.: Design and analysis of ecological experiments, Chapman and Hall, London, 1993.

Seitzinger, S. P. and Sanders, R. W.: Atmospheric inputs of dissolved organic nitrogen stimulate estuarine bacteria and phytoplankton, Limnol. Oceanogr., 44, 721-730, 1999.

Smith, D. C. and Azam, F.: A simple, economical method for measuring bacterial protein synthesis rates in seawater using $3 \mathrm{H}$ leucine, Mar. Microb. Food Webs, 6, 107-114, 1992.

Tanaka, T., Thingstad, T. F., Gasol, J. M., Cardelús, C., Jezberra, J., Sala, M. M., Simek, K., and Unrein, F.: Determining the availability of phosphate and glucose for bacteria in P-limited mesocosms of NW Mediterranean surface waters, Aquat. Microb. Ecol., 56, 81-91, 2009.

Thingstad, T. F. and Sakshaug, E.: Control of phytoplankton growth in nutrient recycling ecosystems. Theory and terminology, Mar. Ecol. Prog.-Ser., 63, 261-272, 1990.

Thingstad, T. F. and Rassoulzadegan, F.: Nutrient limitations, microbial food webs, and "biological C-pumps": suggested interactions in a P-limited Mediterranean, Mar. Ecol. Prog.-Ser., 117, 299-306, 1995.

Thingstad, T. F., Hagström, A., and Rassoulzadegan, F.: Accumulation of degradable DOC in surface waters: Is it caused by a malfunctioning microbial loop?, Limnol. Oceanogr., 42, 398-404, 1997.
Tréguer, P. and Le Corre, P.: Manuel d'analyse des sels nutritifs dans l'eau de mer. Utilisation de l'auto analyseur II, Technicon. L.O.C. Univ. Bretagne Occidentale, Brest, 1975.

Tyrrell, T.: The relative influences of nitrogen and phosphorus on oceanic primary production, Nature, 400, 525-531, 1999.

Van Wambeke, F., Obernosterer, I., Moutin, T., Duhamel, S., Ulloa, O., and Claustre, H.: Heterotrophic bacterial production in the eastern South Pacific: longitudinal trends and coupling with primary production, Biogeosciences, 5, 157-169, doi:10.5194/bg5-157-2008, 2008.

Weisse, T., and Scheffel-Möser, U.: Un coupling the microbial loop: grow and grazing loss rates of bacteria and heterotrophic nanoflagellates in the North Atlantic, Mar. Ecol. Prog.-Ser., 71, 195-205, 1991.

Williams, P. J. leB., and del Giorgio, P. A.: Respiration in aquatic ecosystems: history andbackground, in: Respiration in aquatic ecosystems, edited by: del Giorgio, P. A. and Williams P. J. leB., Oxford University Press, London, 1-18, 2005.

Worden, A. Z., Nolan, J. K., and Palenik, B.: Assessing the dynamics and ecology of marine picophytoplamkton: The importance of the eukaryotic component, Limnol. Oceanogr., 49, 168-179, 2009.

Wu, J., Sunda, W., Boyle, E. A., and Karl, D. M.: Phosphate depletion in Western Atlantic Ocean, Science, 289, 759-762, 2000.

Zubkov, M. V., Sleigh, M. A., Tarran, G. A., Burkill, P. H., and Leakey, R. J. G.: Picoplanktonic community structure on an Atlantic transect from $50^{\circ} \mathrm{N}$ to $50^{\circ} \mathrm{S}$, Deep-Sea Res. Pt. I, 45, 1339-1355, 1998.

Zubkov, M. V., Sleigh, M. A., Burkill, P. H., and Leakey, R. J. G.: Bacterial growth and grazing loss in contrasting areas of North and South Atlantic, J. Plankton Res., 22, 685-711, 2000.

Zweifel, U. L., Norrman, B., and Hagström, A.: Consumption of dissolved organic carbon by marine bacteria and demand for inorganic nutrients, Mar. Ecol. Prog.-Ser., 101, 23-32, 1993. 